\title{
ANALISIS PEMBIAYAAN PRODUKTIF TERHADAP JUMLAH NASABAH PADA KOPERASI KARYAWAN SAMUDERA TONASA LINES KABUPATEN PANGKEP
}

\author{
Muhammad Basir ${ }^{1 *}$, Mulyahati Renreng ${ }^{2 * *}$ \\ ${ }^{1,2}$ Fakultas Ekonomi dan Bisnis Universitas Muslim Maros \\ *muhammadbasir159@gmail.com \\ ***hj.mulyahati@gmail.com
}

\begin{abstract}
ABSTRAK
Penelitian ini bertujuan untuk mengetahui dan menganalisis pemberian pembiayaan produktif dalam meningkatkan jumlah nasabah pada Koperasi Karyawan Samudera Tonasa Lines Kabupaten Pangkep.

Metode analisis Asosiatif, Metode ini digunakan untuk mengetahui hubungan antara dua variable atau lebih dan tidak saling mengikat yang menjelaskan, meramalkan dan mengontrol suatu fenomena.

Hasil penelitian menunjukkan bahwa Koperasi Karyawan Samudera Tonasa Lines Kabupaten Pangkep berhasil meningkatkan pembiayaan produktif terhadap peningkatan jumlah nasabah dalam tiga tahun terakhir dari tahun 2017 hingga tahun 2019.
\end{abstract}

Kata Kunci: Pembiayaan Produktif dan Nasabah

\section{PENDAHULUAN}

\section{A. Latar Belakang}

Koperasi sebagai salah satu lembaga pembiayaan harus dikelola dengan semangat kreativitas dan inovatif dalam memenuhi kebutuhan para anggotanya, bersedia mengambil risiko dan memiliki kepercayaan diri yang kuat dalam menghadapi situasi dan kondisi ekonomi yang tidak menentu.

Karena itu, koperasi harus memiliki peran ganda bagi para anggotanya, baik dalam kedudukannya sebagai pemilik maupun sebagai pelanggan. Sebagai pemilik, anggota koperasi memanfaatkan berbagai potensi atau kesempatan yang disediakan oleh koperasi dalam menunjang kepentingankepentingannya.

Kewirausahaan koperasi sebagai sikap mental positif dalam berusaha secara kooperatif dengan mengambil prakasa,inovatif dan berani mengambil risiko dan berpegang teguh pada prinsip identitas koperasi dalam upaya memenuhi kebutuhan nyata serta peningkatan kesejahteraan bersama (Tanjung,2017:131-132).

Segala bentuk kerjasama itu bertujuan untuk mempertahankan diri terhadap tindakan pihak luar dengan menarik manfaat yang sebesar - besarnya sebagai suatu suasana hidup berkumpul yang mengandung aspek ekonomis dan social Edilius,( $2010: 6$ ).

Penomena yang dihadapi koperasi selama ini adalah kurangnya ketersediaan dana dalam menyalurkan pembiayaan yang produktif kepada para anggotanya/nasabah dan anggota masyarakat lainnya sehingga sebagian anggota koperasi dan anggota masyarakat lainnya mencari pembiayaan di luar koperasi.

Kegiatan pembiayaan koperasi dapat dilakukan antar individu, baik melalui anggota koperasi itu sendiri maupun anggota masyarakat lainnya. Lembaga formal yang menangani khusus di bidang pembiayaan atau 


\section{PAY Jurnal Keuangan dan Perbankan. Vol. 3 No. 1, Juni 2021}

perkreditan adalah lembaga keuangan bank dan lembaga keuangan bukan bank seperti koperasi.

Untuk mengatasi masalah keterbatasan dana bagi koperasi dalam menyalurkan pembiayaan, maka koperasi harus melakukan kemitraan dengan lembaga keuangan lain sehingga koperasi mampu menyediakan dana untuk pembiayaan para anggotanya dan anggota masyarakat lainnya.

Koperasi Karyawan Samudera Tonasa Lines Kabupaten Pangkep sebagai salah satu lembaga pembiayaan/perkreditan senangtiasa memperhatikan ketersediaan dana yang digunakan untuk menyalurkan pembiayaan para anggotanya/ karyawan yang membutuhkan.

Dari uraian tersebut, maka penulis tertarik untuk melakukan penelitian tentang analisis pembiayaan produktif terhadap jumlah nasabah pada Koperasi Karyawan Samudera Tonasa Lines Kabupaten Pangkep.

\section{B. Rumusan Masalah}

Berdasarkan latar belakang yang diuraikan tersebut, maka rumusan masalah dalam penelitian ini adalah Bagaimana pemberian pembiayaan dalam meningkatkan jumlah nasabah pada Koperasi Karyawan Samudera Tonasa Line Kabupaten Pangkep?

\section{Tujuan Penelitian}

Tujuan penelitian ini adalah untuk mengetahui dan menganalisis pemberiaan pembiayaan dalam meningkatkan jumlah nasabah pada Koperasi Karyawan Samudera Tonasa Lines Kabupaten Pangkep.

\section{TINJAUAN PUSTAKA}

\section{A. Pengertian pembiayaan}

Kegiatan pinjam meminjam dana sejak lama dalam kehidupan masyarakat yang telah mengenal uang sebagai alat pembiayaan. Kegiatan pinjam meminjam dana sebagai sesuatu yang sangat diperlukan bagi seluruh masyarakat untuk mendukung perkembangan kegiatan perekonomian dan peningkatan taraf hidup masyarakat. Dana pinjaman tersebut menghasilkan bunga dan dari bunga inilah terbentuk dana yang dipergunakan untuk membiayaai semua kegiatan untuk melayani kebutuhan masyarakat yang memerlukan jasa pada badan usaha koperasi.

Denda Wijaya (2005:61) Mengemukakan bahwa pembiayaan /dana pinjaman kepada masyarakat adalah suatu pencegahan rakyat kecil yang membutuhkan pinjaman agar tidak jatuh ketangan para pelepas uang (rentenir) yang mengenakan bunga dengan nilai yang sangat tinggi dan berlipat ganda.

Salah satu syarat keberhasilan usaha koperasi adalah prinsip identitas harus dapat diterapkan dan syarat - syarat minimal berupa kondisi yang dapat menunjang koperasi yang bersangkutan (Subyantoro dan Sudaryoto, 2015:2728).

\section{B. Pengertian Nasabah}

Nasabah adalah orang atau badan yang mempunyai rekening simpanan atau pinjaman pada bank menurut Saladin (1994). Sedangkan Komaruddin (1994) mengatakan bahwa nasabah adalah seseorang atau suatu perusahaan yang mempunyai rekening Koran atau deposito atau tabungan serupa lainnya pada sebuah bank.

Dari pengertian tersebut, nasabah merupakan orang atau sekelompok orang yang melakukan kegiatan transaksi pada sebuah lembaga keuangan, baik lembaga keuangan bank maupun lembaga keuangan bukan bank seperti koperasi. 


\section{PAY Jurnal Keuangan dan Perbankan. Vol. 3 No. 1, Juni 2021}

\section{Klasifikasi Nasabah}

Mulyono, (2006) Mengemukakan bahwa klasifikasi nasabah dapat dilihat dengan matriks klasifikasi nasabah pembiayaan. Matriks tersebut menggabungkan antara aspek jaminan dan manajemen. Nasabah ini memiliki pemahaman karakteristik, fitur dan risiko dari struktur produk yang terdiri dari

Nasabah diklasifikasikan menjadi tiga yaitu :

1. Nasabah profesional

Nasabah ini di golongkan sebagai nasabah profesional apabila nasabah tersebut memiliki pemahaman terhadap karakteristik, fitur, dan risiko dari struktur produk yang terdiri dari :

a. perusahaan yang bergerak dibidang keuangan yang terdiri dari bank, perusahaan efek, perusahaan pembiayaan atau pedagang berjangka.

b. Pemerintah Republik Indonesia atau pemerintah negara lain.

2. Nasbah Eligible

Nasabah ini memiliki pemahaman karakteristik, fitur dan risiko dari struktur produk yang terdiri dari:

a. perusahaan yang bergerak dibidang keuangan berupa dana pensiun atau perusahaan perasuransian sepanjang tidak bertentangan dengan peraturan perundang-undangan dibidang dana pensiun dan usaha perasuransian yang berlaku.

b. perusahaan dengan modal minimal Rp. 5.000.000.000 (lima miliyar rupiah) atau ekuivalennya dalam valuta asing dan telah melakukan kegiatan minimal 12 bulan berturut - turut.

3. Nasabah Retail

Nasabah retail adalah nasabah yang tidak termasuk dalam nasabah profesional dan eligible. Struktur produk adalah produk bank yang merupakan penggabungan antara dua atau lebih instrumen keuangan berupa instrumen keuangan non derevatif dengan derevatif atau memiliki karakteristik yaitu arus kas yang timbul dari produk tersebut dikaitkan dengan satu atau kombinasi variabel dasar seperti suku bunga, nilai tukar, komoditi dan atau ekuitas. nasabah perorangan yang mempunyai portofolio asset berupa kas,

\section{METODE ANALISIS}

Metode yang digunakan dalam menganalisis data adalah metode asosiatif yaitu metode yang dapat menghubungkan dua variable atau lebih (Qurtubi, 2008). Metode ini memberikan hubungan antara dua variable atau lebih dan tidak saling mengikat.

\section{HASIL PENELITIAN}

\section{A. Analisis Pemberian Pembiayaan}

Pemberian pembiayaan pada Koperasi Karyawan Samudera Tonasa Lines Kabupaten Pangkep adalah :

Tabel 1. Pembiayaan Koperasi Karyawan Samudera Tonasa Lines Kabupaten Pangkep Tahun 2017 2019

\begin{tabular}{cl} 
Tahun & \multicolumn{1}{c}{ Pembiayaan } \\
2017 & Rp. $\quad 500.000 .000$ \\
2018 & RP. 1.000 .000 .000 \\
2019 & Rp. 1.500 .000 .000
\end{tabular}

Sumber : Koperasi Karyawan Samudera Tonasa Lines Kabupaten Pangkep

Berdasarkan data di atas, pembiayaan pada koperasi karyawan samudera tonasa lines kabupaten pangkep selama tiga tahun terakhir dari tahun 2017 hingga 2019 mengalami kenaikan secara signifikan. Meningkatnya pembiayaan koperasi 


\section{PAY Jurnal Keuangan dan Perbankan. Vol. 3 No. 1, Juni 2021}

karyawan samudera tonasa lines sebagai akibat tingginya minat nasabah untuk mendapatkan pembiayaan untuk melakukan aktivitas usaha di berbagai bidang usaha yang memiliki prospek yang menggembirakan.

\section{B. Analisis Pembiayaan Terhadap Nasabah dan Persentasenya}

Pemberian pembiayaan kepada setiap nasabah dan persentasenya pada Koperasi Karyawan Samudera Tonasa Lines Kabupaten Pangkep

Tabel 2. Jumlah Pembiayaan Terhadap Nasabah dan Persentasenya

$\begin{array}{ccc}\text { Tahun } & \begin{array}{c}\text { Pembiayaan/ } \\ \text { Nasabah }\end{array} & \text { Persentase } \\ 2017 & \text { Rp. } 43.000 .000 & 0 \\ 2018 & \text { Rp. } 50.000 .000 & 15 \% \\ 2019 & \text { Rp. } 75.000 .000 & 50 \%\end{array}$

Sumber: Data diolah, 2019

Berdasarkan tabel tersebut, jumlah pembiayaan yang diberikan kepada setiap nasabah selama tiga tahun terakhir dari tahun 2017 hingga tahun 2019 mengalami kenaikan yaitu dari tahun 2017 ke tahun 2018 jumlah pembiayaan meningkat sebesar Rp.7.000.000 dengan persentase sebesar $15 \%$ sedangkan dari tahun 2018 ke tahun 2019 meningkat sebesar Rp. 25.000.000 dengan persentase sebesar $50 \%$.

Meningkatnya jumlah pembiayaan bagi setiap nasabah Koperasi Karyawan Samudera Tonasa Lines Kabupaten Pangkep sangat dipengaruhi oleh iklim ekonomi yang kondusif sehingga terbuka peluang untuk memperluas jaringan usaha karena kondisi pasar semakin bergairah.

\section{KESIMPULAN}

Berdasarkan hasil penelitian dan pembahasan yang telah diuraikan tersebut, maka dapat ditarik simpulan sebagai berikut dilakukan analisis data pemberian pembiayaan terhadap jumlah nasabah Koperasi Karyawan Samudera Tonasa Lines Kabupaten Pangkep, maka dapat diketahui bahwa jumlah pembiayaan yang diberikan setiap nasabah menunjukkan terjadi kenaikan karena didukung oleh iklim ekonomi yang kondusif dan kondisi pasar semakin bergairah untuk memperluas jaringan usaha.

\section{SARAN}

Saran yang dapat diberikan guna membantu Koperasi Karyawan Samudera Tonasa Lines Kabupaten Pangkep yang dapat dijadikan sebagai bahan pertimbangan di masa mendatang adalah sebaiknya Koperasi Karyawan Samudera Tonasa Lines Kabupaten Pangkep lebih meningkatkan jumlah pembiayaan produktif terhadap jumlah nasabah agar aktivitas usaha koperasi semakin meningkat dalam menghadapi tingkat persaingan usaha yang semakin kompetitif.

\section{DAFTAR PUSTAKA}

Arief Subyantoro, Aryono Yacobus Sudaryoto, 2015. Manajemen Koperasi, Gosyen Publishing, Yogyakarta.

B., A. Tawakkal, Muhammad Basir \& Muh. Alam Nasyrah Hanafi. 2019. Analisis Penentuan Biaya Tetap dan Biaya Variabel dalam Meningkatkan Laba pada Outlet the Coffee Bean \& Tea Leaf Grand Indonesia di Kota Makassar. PAY Jurnal Keuangan dan Perbankan, Vol.1 No.2, 107-115. https://ejournals.umma.ac.id/index .php/pay/article/view/408.

Djaslin, Saladin, 1994. Dasar - Dasar Manajemen Pemasaran Bank, Mandar Maju, Bandung.

Komaruddin, 1994. Kamus Perbankan, CV. Rajawali, Jakarta.

Lukman Dendawijaya, 2015. Manajemen Perbankan, Ghalia Indonesia Bogor.

M.Azrul Tanjung, 2017. Koperasi dan UMKM, Erlangga, Jakarta. 
PAY Jurnal Keuangan dan Perbankan. Vol. 3 No. 1, Juni 2021

Qurtubi, A, 2008. Metodologi Penelitian Pendidikan, PT. Bintang Harapan Sejatera, Tangerang.

Sudarsono, Edilius, 2010. Manajemen

Koperasi Indonesia, Rineka Cipta, Jakarta.

Teguh Pudjo, Mulyono, 2006. Manajemen Perkreditan Bagi Bank Komersial, BPFE, Yogyakarta. 